\title{
The correlation of structural and binding affinity of insulin analog to the onset of action for diabetic therapy
}

DOI: https://doi.org/10.22435/hsji.v12i1.4783

\author{
Galuh Wening Permatasari ${ }^{1}$, Didik Huswo Utomo ${ }^{2,3}$, Dian Laila Purwaningroom ${ }^{4}$, Djoko Soeatmadji ${ }^{5}$ \\ ${ }^{1}$ Indonesian Research Institute for Biotechnology and Bioindustry, Bogor, Indonesia \\ ${ }^{2}$ Research and Education Center for Bioinformatics, Nusantara Institute for Life Science and Technology, \\ Malang, Indonesia \\ ${ }^{3}$ Department of Applied Biosciences, Nagoya University, Japan \\ ${ }^{4}$ Department of Nursing, Faculty of Health Sciences, Universitas Muhammadiyah Ponorogo, Ponorogo, \\ Indonesia \\ ${ }^{5}$ Department of Internal Medicine Laboratory, Faculty of Medicine, Brawijaya University, Malang, Indonesia
}

Corresponding author: Galuh Wening Permatasari

Email: galuh.wening@gmail.com

Received: January 20, 2021; Revised: May 7, 2021; Accepted: June 11, 2021.

\begin{abstract}
Background: These days, insulin analog production has been improved and becoming popular. The advantages of insulin analog have been extensively reviewed in terms of effectiveness compared to human insulin. Each of the insulin analog industries has claimed their safety and efficacy based on in vivo and in vitro to overcome type 2 diabetes. Hereby, we report on the identification of highly effective analog-based insulin on structure and binding affinity computationally, to confirm its potential and give a broader point of view to insulin analog users.

Methods: Five types of insulin analogs, Aspart, Glargine, Detemir, Lispro and Degludec, were analyzed. We grouped and clustered the sequence by alignment to identify the closeness and sequence similarity between samples, continued by superimposing analysis and undertaking binding affinity identification utilizing of a docking analysis approach.

Results: Lispro had the least sequence similarity to other types, close to Aspart (96\%) and Glargine (90.5\%), while Detemir and Degludec showed 100\% similarity we decide to only use Degludec for the next analysis. Furthermore, Lispro, Aspart, and Glargine exhibited structural similarity strengthened by the lack of significant difference in the RMSD data. Importantly, Aspart had the highest binding affinity score $(-66.1+/-7.1 \mathrm{Kcal} / \mathrm{mol})$ in the docking analysis to the insulin receptor (INSR) and similar binding site areas to human insulin.
\end{abstract}

Conclusion: Our finding revealed that the strength of insulin analogs towards insulin receptors is identic with its rapid mechanism in the human body. (Health Science Journal of Indonesia 2021;12(1):47-55)

Keywords: Computation, Docking, Insulin analog, Sequence similarity, Structure

\begin{abstract}
Abstrak
Latar belakang: Saat ini, produksi analog insulin meningkat dan menjadi popular. Keuntungan analog insulin telah ditinjau secara ekstensif dalam hal efektivitas dibandingkan dengan insulin manusia. Masingmasing industri analog insulin mengklaim keamanan dan kemanjurannya berdasarkan in vivo dan in vitro untuk mengatasi diabetes tipe 2. Kami melaporkan identifikasi insulin analog yang efektif berdasarkan struktur dan afinitas pengikatan secara komputasi, untuk mengonfirmasi potensi serta memberikan sudut pandang yang lebih luas kepada pengguna insulin analog.

Metode: Lima jenis analog insulin, Aspart, Glargine, Detemir, Lispro, dan Degludec, dianalisis. Kami membandingkan dan mengelompokkan urutan tersebut dengan penyelarasan untuk mengidentifikasi kedekatan dan kesamaan urutan antar sampel dilanjutkan dengan analisis superimpose dan melakukan identifikasi ikatan afinitas menggunakan pendekatan analisis docking.
\end{abstract}


Hasil: Lispro memiliki kemiripan sekuen paling rendah dengan jenis lainnya, mendekati Aspart (96\%) dan glargine (90,5\%), sedangkan Determir dan Degludec menunjukkan kemiripan 100\% sehingga kami menggunakan Degludec untuk analisis selanjutnya. Selain itu, Lispro, Aspart, dan Glargine menunjukkan kesamaan struktural yang diperkuat oleh rendahnya nilai signifikansi pada data RMSD. Perlu digarisbawahi bahwa Aspart memiliki skor afinitas pengikatan tertinggi $(-66.1+/-7.1 \mathrm{kkal} / \mathrm{mol})$ dalam analisis docking ke reseptor insulin (INSR) dan memiliki area pengikatan yang serupa dengan insulin manusia.

Kesimpulan: Penemuan kami mengungkapkan bahwa kekuatan insulin analog sejalan dengan laju mekanismenya di dalam tubuh manusia. (Health Science Journal of Indonesia 2021;12(1):47-55)

Kata kunci: Komputasi, Docking, Insulin analog, Kemiripan sekuen, Struktur

Insulin analog manufacturing has been upgraded and the production of human insulin using recombinant DNA has become common. Historically, as well as studies of the advantages of an insulin analog, have been extensively reviewed regarding of effectiveness compared to human insulin., ${ }^{1,2}$ The finding of insulin in 1922 in people with diabetes, marked a significant development in medicine and care. Long time before insulin was detected, it was thought that the pancreas secreted a compound that regulated the digestion of carbohydrates. ${ }^{3}$ Whereas for years, owing to impurities and toxicities, need an efforts to prepare pancreatic extracts to reduce blood glucose have failed ${ }^{4}$ The concept of isolating pancreatic islet extracts by inserting the pancreatic duct of dogs was developed by Frederick Banting, an orthopedic surgeon, who holding them intact until the acini deteriorated, leaving the islets for isolation. Working with John Macleod, by 1921, they revealed that the de-pancreatised dog developed diabetes and that the blood glucose was decreased by intravenous injection of their pancreatic extract, which called "Isletin". ${ }^{4}$

Since the preparation of insulin involved many regular doses, investigators is seeking ways to increase its time of action. Many researchers such as Hagedorn from Denmark also Scott and Fisher in Toronto developed insulin activities, ${ }^{3}$ until the result is contributed to launch of industry for longer-acting animal insulin. Zinc insulin protamine itself is lasted for 24-36 hours. Meanwhile, Hagedorn's isophane neutral protamine is lasted for 24 hours and could be combined with the normal insulin. David Goeddel and his coworkers (of Genentech) prepared the first DNA Recombinant human insulin in 1978 by using and integrating the insulin A- and B- toexpressed in Escherichia coli. The agreementto commercialize rDNA insulin was eventually signed by Genentech and Lilly. In 1982, Humulin ${ }^{\circledR}$ R (rapid) and N (NPH, intermediate-acting), the first insulin using rDNA technology which is referred to as analog, were marketed. ${ }^{1}$
Insulin analogs are synthetically produced insulin variants that differ from those of native human insulin in the amino acid chain. ${ }^{5}$ Insulin analog has two modes of operating time: fast-acting and long-acting. Rapid-acting analog insulins have a faster effect than short-acting insulins in humans or animals. The analogs may be taken either before or after a meal, although the latter are generally taken 15 to 30 minutes before the meal. For the person who needs more consistency in meal times, rapid insulin could be an appropriate choice. Genereally, longacting analogs are taken at bedtime for once in a day and appear to have a comparatively smooth operation that lasts between 16 and 24 hours. For basal-bolus regimens of insulin delivery, both fast- and longacting analog insulins are well adapted, but insulin analogs are not equivalent to other of insulin types. Their advantage is they are offer greater versatility. ${ }^{6}$

Positioned modification of amino acids in the insulin improved the pharmacokinetics and led to quicker absorption, an earlier peak of action, and a shorter duration of action. ${ }^{7}$ The first short-acting insulin analog approved in 1996 was Lispro, ${ }^{8}$ followed by Aspart in $2000^{9}$ and Glulisine in 2004. ${ }^{10}$ Two basal insulin analogs, Glargine, approved in $2000,{ }^{11}$ and Detemir, approved in 2005, are currently available on the market. ${ }^{12}$ Glargine has glycine at position A21 instead of asparagine, a further two molecules of arginine at position $\mathrm{B} 30$, and a $\mathrm{pH}$ of 4.0. At the injection site, it forms microprecipitates which result in sustained absorption with little peak activity. ${ }^{11,13}$ At location B29, Detemir has a 14-carbon fatty acid chain bound to lysine that delays its absorption. ${ }^{12}$ The insulin analog usage in the clinical were obviously have more benefit to compare with the regular insulin. One of them is the deprivation of hypoglycemia and gaining weight evidence. The glargine and detemir insulin were approved to decrease the nocturnal hypoglycemia compare to regular insulin, by $42-$ $48 \%$ and $34 \%$, respectively. ${ }^{14}$

However, despite of the insulin analogues technology development, there are recently a cohort study 
comparation of human insulin and insulin analogues administration. According to data, the senior patients with type $2 \mathrm{DM}$ switching the plan from insulin analogues to human insulin and it showed only $0.14 \%$ glycemic changes with no manifestation of hypoglycemic or hyperglycemic. ${ }^{15}$ Therefore, further consideration is needed in terms of human insulin usage, especially associated with the cheaper cost, ${ }^{16}$ given that people can get the human insulin only for USD 25 per vial at Walmart. ${ }^{17-20}$

Our questions and hypothesis consider whether the insulin analogs' mode of action is related to its amino acid composition as well as its protein structure. Moreover, the affinity binding that form once after the insulin analogs docks with an insulin receptor would be a part of the factor that influences the rapid action of each analog. Hereby, we report about the identification of highly effective insulin analogs based on the structure and binding affinity with the receptor, a human insulin receptor, using an in-silico approach to confirm their potential and give a broader point of view for insulin analog users.

\section{METHODS}

\section{Sample retrieval and protein modeling}

The amino acid sequence of Aspart, Glargine, Detemir, Lispro and Degludec were retrieved from the drugbank database (https://www.drugbank.ca/), while the human insulin sequences (ID P01308) were retrieved from the Uniprot database (https:// uniprot.org). The 3D structure of the human insulin receptor (hINSR) (ID 1GAG) and human insulin (hINS) (ID 3W11) were downloaded from the PDB database, while the insulin analog structures were built and constructed using I-TASSER software. The structure models were chosen based on the four considerations including (1) the highest rank of TM-score of the structural alignment between the query structure and template structures in the PDB database; (2) the lowest Root Mean Square Deviation (RMSDa) score which represents the smallest deviation between residues; (3) the highest IDENa, representing the highest similarity in terms of percentage of sequence identity; and (4) the highest Cov score that represents the coverage of alignment by TM-align. ${ }^{21}$ The 3D structure for each insulin was compared using Superpose V.10 software to reveal the RMSD differences.

\section{Similarity analysis for insulin sequence and 3D structure}

To reveal the nucleotide sequence variation between canonical hINS and the insulin analogs Aspart, Glargine, Detemir, Lispro and Degludec, local blast was performed utilizing CLUSTAL-W and visualized using BioEdit software. ${ }^{22}$ Clustering and phylogenetic tree construction for each insulin sequence were built using MEGA7 software to point out the similarity between the analog insulin. Using the Maximum Likelihood method based on the Tamura-Nei model, the evolutionary history was built. ${ }^{23}$ The tree with the highest log probability was built and the percentage of trees in which the associated taxa is clustered next to the substation until itshown. By applying Neighbor-Join and BioNJ algorithms to a matrix of pairwise distances estimated using the Maximum Composite Likelihood (MCL) approach, initial tree(s) for the heuristic search were obtained automatically and then the topology with a higher $\log$ probability value was selected.

Later, the RMSD scores were evaluated by SuperPose V1.0 webserver (http://superpose. wishartlab. com/). SuperPose is designed to accommodate five categories of criteria for macromolecular superposition: (a) superposition of two or more molecules with the same sequence but with a significantly different structure; (b) superposition of two molecules with the same sequenc, but with a deeply different structure; (c) the overlap of two or more molecules of modestly different sequence, length and composition; (d) the overlap of two or more molecules of profoundly different lengths but identical structure or sequence; and (e) the overlap of two or more molecules of profoundly different sequence in similar structure. ${ }^{24}$

\section{Molecular docking analysis}

In order to understand the molecular interaction between human insulin, the insulin analogs and insulin receptors (IR) analysis was carried out using HADDOCK v2.2 software (https://alcazar.science. uu.nl/ services/HADDOCK2.2/). ${ }^{26}$ The docking analysis was directed to specific site of hINSR located in the L1 region $705-715,{ }^{27}$ while hINS active sites were located in amino acid numbers from 1 to 21 . The docking method was used to compare the binding affinities between insulin each analog in order to discover the most effective insulin analog. Results of docking and bonding interactions were visualized using PyMol software ${ }^{25}$ and Discovery Studio R2 2017 software. 


\section{RESULTS}

\section{Sequence and pairwise alignment}

There are five types of insulin analog sequences including Aspart, Glargine, Detemir, Lispro and Degludec were aligned to each other. The results shows that among the five types of insulin analogs, reach out the similarity for $99 \%$ (Figure 1). Among the insulin analogs, the differentiation was found in 21st amino acid of Glargine from asparagine (N) to glycine (G). Meanwhile, the sequence similarity between insulin analogs and canonical hINS revealed a quite big difference, around 70$80 \%$ from the form a pairalignment analysis. The conservation region from six insulin samples was 27 amino acids (see Figure 1) as follows: FVNQHLCGSHLVEALYLVCGERGFFYT. Also, the conservation sequence located in hINS and insulin analogs were identified at amino acid numbers 25 to
50 based on the hINS sequence. Moreover, the most noticeable difference among the sequences was in the $\mathrm{C}$-terminal region of the insulin.

Further, the similarities value was calculated by form a pair alignment methods deciphering the closeness of each insulin analog. Degludec and Detemir had the highest values with scores of 1.0, which following by Lispro and Aspart with scores of 0.96. While Glargin and hINS had the highest score, which 0.3 compared to other insulin analogs with only 0.27 . Visualization and construction of the phylogenetic tree definethe closeness for each insulin (Figure 2). There are two clusters built in the dendogram tree, that is Aspart and Lispro were in same cluster with 67 bootstrap values, while the second cluster consists of Degludec and Detemir supported by a subsidiary strength score of 35. Insulin Glargin was the closest one to the canonical human insulin as shown by the short distance in the phylogenetic tree. Those furthest from hINS were Insulin Lispro and Insulin Aspart.

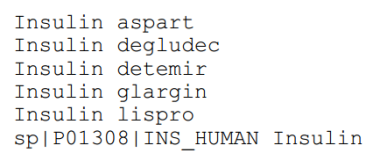

Insulin aspart

Insulin glargi

sp|P01308|INS_HUMAN Insulin

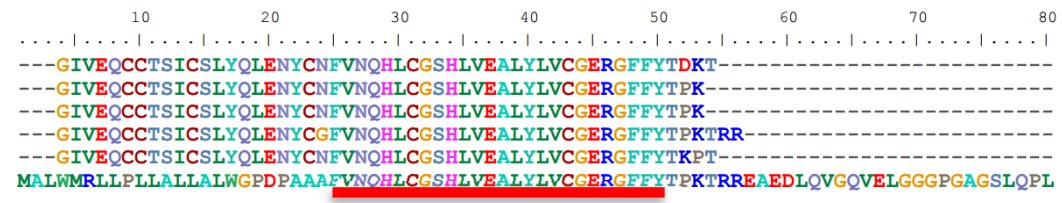

Figure 1. Local alignment between five insulin analogs and human insulin

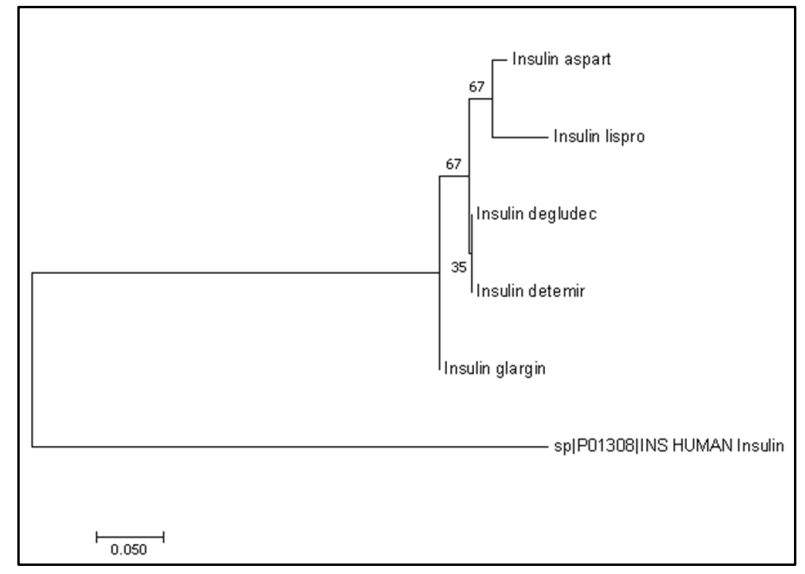

Figure 2. Phylogenetic tree of insulin analogs and human insulin

\section{Root mean square deviation (RMSD) analysis of insulin analogs' structure}

Because of the high similarities found in the Detemir and Degludec, we decide to choose for only one insulin analog. Insulin Detemir was eliminated from further analysis. The 3D structure analysis among insulin analogs and hINS generally shows a high similarity, as shown by the non-significant difference in the RMSD data. The range of RMSD scores for each insulin is 3.738 to 4.342 . The highest RMSD was found in the Aspart vs Glargine at 4.342, while the lowest isAspart vs hINS at 3.738. The concrete researchfrom the sequence and structure similarity analysis are demonstrated in the Aspart and Lispro insulin which had high RMSD scores (4.05). A similar contrivancesupporting the sequence alignment and phylogenetic showedin Glargin and hINS with a low RMSD score (3.852). This contrivance also supported by superposing the visualization foreach insulin (Figure 3F). 
Table 1. The RMSD score among insulin analogs and human insulin

\begin{tabular}{ccccccc}
\hline \multirow{2}{*}{ No } & \multirow{2}{*}{ Protein A } & \multirow{2}{*}{ Protein B } & \multicolumn{3}{c}{ Local RMSD } \\
\cline { 4 - 7 } & & Alpha carbons & Back Bone & Heavy & All \\
\hline 1 & Aspart & Degludec & 3.505 & 3.495 & 3.505 & 4.063 \\
2 & Aspart & Glargin & 3.815 & 3.765 & 4.32 & 4.342 \\
3 & Aspart & Lispro & 3.573 & 3.548 & 4.008 & 4.05 \\
4 & Degludec & Glargin & 3.41 & 3.378 & 4.04 & 4.07 \\
5 & Degludec & Lispro & 3.573 & 3.533 & 4.06 & 4.125 \\
6 & Glargin & Lispro & 3.603 & 3.553 & 4.108 & 4.172 \\
7 & Lispro & Insulin human & 3.597 & 3.55 & 3.958 & 4.015 \\
8 & Glargin & Insulin human & 3.53 & 3.523 & 3.818 & 3.852 \\
9 & Degludec & Insulin human & 3.555 & 3.568 & 3.935 & 4.028 \\
10 & Aspart & Insulin human & 3.273 & 3.282 & 3.668 & 3.738 \\
\hline
\end{tabular}

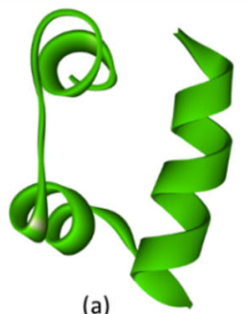

(a)

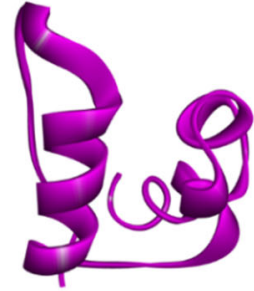

(d)

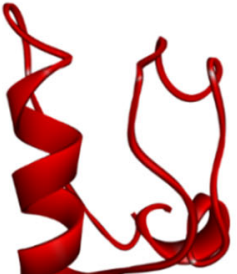

(b)

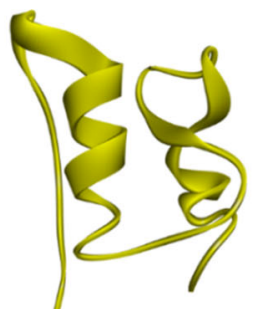

(e)

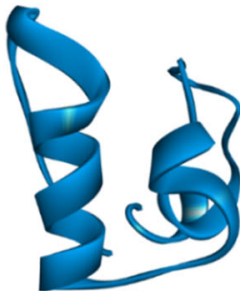

(c)

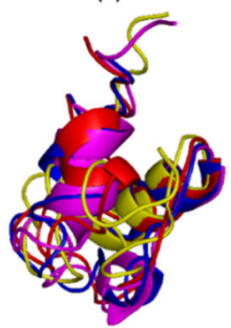

(f)

Figure 3. Visualization of 3D structure insulin analogs (a) human insulin (hINS), (b) insulin Aspart (c) insulin Degludec, (d) insulin Glargine, (e) insulin Lispro, (f) superimposition of insulin structures

\section{Molecular docking analysis}

Since molecular interaction is important to define the activity and efficacy of insulin to control glucose levels, binding affinity analysis is the next step then. In order to reveal the interaction strength formed by the insulin and insulin receptor, specific docking analysis was used to simulate the interaction. The Aspart and hINSR have the highest binding affinity $(-66.9+/-6.2 \mathrm{kcal} / \mathrm{mol})$, which higher than hINShINSR complex with $-66.1+/-7.1 \mathrm{kcal} / \mathrm{mol}$. The other insulin analogs' affinity was below from the hINS-hINSR. Despite differences in the affinity score after docking, the binding site for each insulin analog was almost similar to the others, as shown in Table 3 , and the visualization of docking is shown in Figure 4. There were two interaction forces which occurred in the complex of insulin and hINSR, hydrogen and hydrophobic forces. The forces number is fairly similar, and it causes thatwe cannot conclude which forces dominate the interaction. The hydrogen-bond
(H-bond) is primarily an electrostatic relationship usually modeled by using Coulomb-type-equations, and a crucial component for this is the dielectric constant. Unfortunately, it is not an accurate and easy method for measuring the dielectric constant. In addition, the H-bond modeling, havea difficulty forthe high heterogeneity of various forms and strengths of H-bonds. As seen with water content of $\mathrm{H}$-bonds, ${ }^{28}$ hydrogen bonds (H-bonds even the atmosphere has an enormous effect.

Table 2. Binding affinity of insulin for human insulin receptor (hINSR) using molecular docking

\begin{tabular}{clc}
\hline Receptor & \multicolumn{1}{c}{ Ligand } & $\begin{array}{c}\text { Binding Affinity } \\
\text { (kcal/mol) }\end{array}$ \\
\hline \multirow{2}{*}{ hINSR } & hINS & $-66.1+/-7.1$ \\
& Aspart & $-66.9+/-6.2$ \\
& Glargin & $-57.6+/-3.8$ \\
& Lispro & $-60.4+/-3.3$ \\
& Degludec & $-55.9+/-5.8$ \\
\hline
\end{tabular}




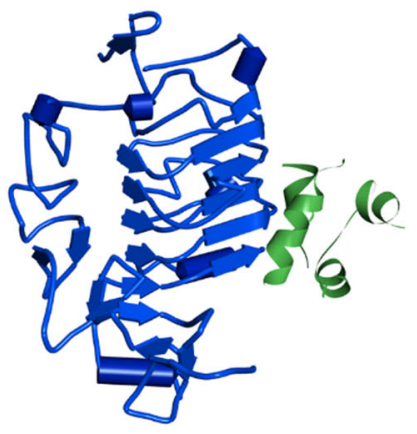

(a)

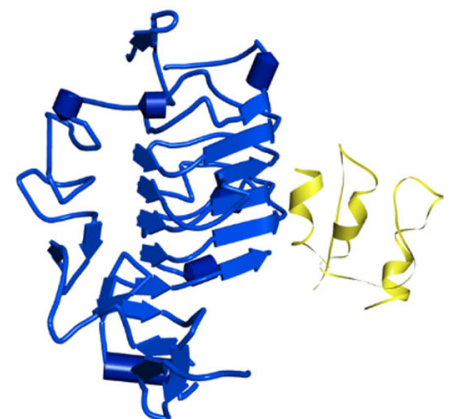

(b)

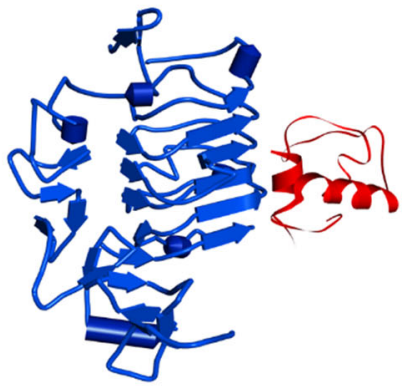

(c)

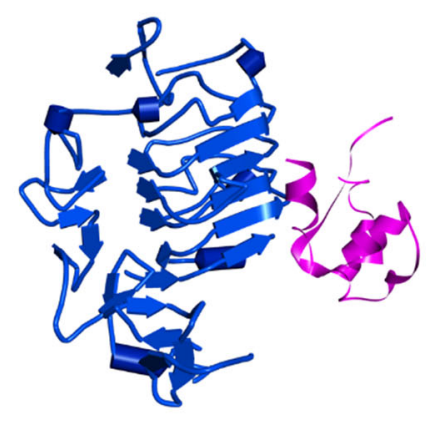

(d)

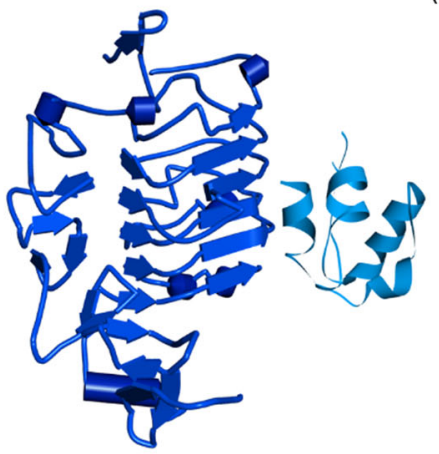

(e)

Figure 4. Visualization of docking results between hINSR (blue, ribbon) and (a) hINS (green), (b) Lispro (yellow), (c) Aspart (red), (d) Glargin (magenta), (e) Degludec (light blue)

Table 3. Molecular interaction analysis of insulin and human insulin receptor

\begin{tabular}{|c|c|c|c|c|c|c|c|c|c|c|}
\hline \multirow{2}{*}{$\begin{array}{c}\text { Type of } \\
\text { Bond }\end{array}$} & \multicolumn{2}{|c|}{ INSR-INS } & \multicolumn{2}{|c|}{ INSR-Aspart } & \multicolumn{2}{|c|}{ INSR-Glargin } & \multicolumn{2}{|c|}{ INSR-Lispro } & \multicolumn{2}{|c|}{ INSR-Degludec } \\
\hline & INSR & Insulin & INSR & Aspart & INSR & Glargin & INSR & Lispro & INSR & Degludec \\
\hline $\begin{array}{l}\text { Hydro- } \\
\text { phobic }\end{array}$ & $\begin{array}{l}\text { HIS710, } \\
\text { VAL } 712, \\
\text { GLU706 }\end{array}$ & $\begin{array}{l}\text { ILE10, } \\
\text { VAL33, } \\
\text { LEU16, } \\
\text { SER12, } \\
\text { LEU32, } \\
\text { ALA29 }\end{array}$ & $\begin{array}{l}\text { PHE714, } \\
\text { VAL 715, } \\
\text { VAL } 717,\end{array}$ & $\begin{array}{l}\text { PHE45, } \\
\text { THR51, } \\
\text { TYR47, } \\
\text { CYS40, } \\
\text { GLU17, } \\
\text { ILE2, } \\
\text { LEU36, } \\
\text { LEU16, } \\
\text { GLN5, }\end{array}$ & LEU709 & $\begin{array}{l}\text { GLU4, } \\
\text { GLN15, } \\
\text { LEU16, } \\
\text { VAL39, } \\
\text { PHE45, } \\
\text { GLY44, } \\
\text { TYR19, } \\
\text { LEU36, } \\
\text { ILE2, } \\
\text { GLY1, } \\
\text { PHE46 }\end{array}$ & $\begin{array}{l}\text { VAL715, } \\
\text { PHE714, } \\
\text { ARG14, } \\
\text { VAL712, } \\
\text { HIS710, } \\
\text { GLU706 }\end{array}$ & $\begin{array}{l}\text { CYS6, } \\
\text { HIS31, } \\
\text { CYS28, } \\
\text { THR51, } \\
\text { GLY29, } \\
\text { THR47, } \\
\text { THR48, } \\
\text { PHE45, } \\
\text { LEU36, } \\
\text { PHE46, } \\
\text { ARG43, } \\
\text { TYR37, } \\
\text { GLY44 }\end{array}$ & $\begin{array}{l}\text { HIS710, } \\
\text { PHE714, } \\
\text { VAL 713 }\end{array}$ & $\begin{array}{l}\text { PHE46, } \\
\text { GLY44, } \\
\text { TYR47, } \\
\text { ILE2, } \\
\text { PHE45, } \\
\text { CYS11, } \\
\text { VAL39, } \\
\text { LEU16, } \\
\text { ILE10, } \\
\text { GLU17, } \\
\text { TYR19 }\end{array}$ \\
\hline Hydrogen & $\begin{array}{l}\text { VAL715, } \\
\text { PHE714, } \\
\text { ASN712, } \\
\text { TYR708, } \\
\text { PHE705, } \\
\text { ASP707, }\end{array}$ & $\begin{array}{l}\text { TYR14, } \\
\text { LEU13, } \\
\text { CYS6, } \\
\text { GLU28, } \\
\text { CYS11, } \\
\text { HIS25, } \\
\text { CYS11, } \\
\text { HIS25, } \\
\text { CYS22, } \\
\text { GLU36, } \\
\text { LEU26, } \\
\text { SER24, } \\
\text { GLY23 }\end{array}$ & $\begin{array}{l}\text { HIS710, } \\
\text { ASN711, } \\
\text { TYR708, } \\
\text { ASP707, } \\
\text { GLU706, } \\
\text { PHE705 }\end{array}$ & $\begin{array}{c}\text { GLY1, } \\
\text { THR48, } \\
\text { GLU4, } \\
\text { PHE64, } \\
\text { ARG43, } \\
\text { CYS6, } \\
\text { TYR19, } \\
\text { CYS11, } \\
\text { GLN15, } \\
\text { TYR14 }\end{array}$ & $\begin{array}{l}\text { ASN711, } \\
\text { ASP707, } \\
\text { GLU706, } \\
\text { VAL715, } \\
\text { PHE714, } \\
\text { VAL713, } \\
\text { ARG14, } \\
\text { VAL712, } \\
\text { HIS710 }\end{array}$ & $\begin{array}{c}\text { SER9, } \\
\text { GLN5, } \\
\text { LYS50, } \\
\text { ARG52, } \\
\text { CYS40, } \\
\text { ARG43, } \\
\text { THR48, } \\
\text { GLU42, } \\
\text { CYS6 }\end{array}$ & $\begin{array}{l}\text { VAL 713, } \\
\text { ASN711, } \\
\text { ASP707 }\end{array}$ & $\begin{array}{l}\text { LYS49, } \\
\text { GLU34, } \\
\text { SER30, } \\
\text { VAL33, } \\
\text { GLY41, } \\
\text { CYS40, } \\
\text { GLY41, } \\
\text { CYS40 }\end{array}$ & $\begin{array}{l}\text { GLU706, } \\
\text { ASP707, } \\
\text { VAL715, } \\
\text { ASN711, } \\
\text { VAL712, } \\
\text { TYR708 }\end{array}$ & $\begin{array}{c}\text { THR48, } \\
\text { GLY1, } \\
\text { GLN5, } \\
\text { ARG43, } \\
\text { CYS6, } \\
\text { GLN15, } \\
\text { TYR14 }\end{array}$ \\
\hline
\end{tabular}




\section{DISCUSSION}

Our finding is revealed that the difference among five insulin analogs sequences is located in the C-terminal region. This might be related to the C-peptide activity, which acted out as a peptide similar to a hormone, and most certainly affirms a receptor's presence. There must be a limited region of the ligand who acted out as an active site in the classic ligand-receptor interaction manner, to influence the binding receptor, which normally well preserved around species boundaries. ${ }^{29}$ Based on the report from Shuai et al,,$^{30}$ the C-peptide execute a crucial role in co-evolution and during evolution is had important sequence characteristics, which confirms the statement that C-peptide can behave as a hormone-like cytokine who have important functions in diabetes pathophysiology also care, and it can grow more like a biological factor with a major correlation and restriction in residue mutation. In addition, Ido et al, ${ }^{31}$ to propose that the $\mathrm{C}$-peptide midportion chain mainly conserved and contained a high proportion of nonpolar amino acids, who involved in the action of the ligand. Moreover, the C-terminal pentapeptide C-peptide coevolutionary residues 86 (Leu) and 87 (Gln) of human proinsulin might be involved in mysterious active sites of the C-peptide itself and engage in interaction with unique receptor. ${ }^{32-34}$ Based on the literature, the C-terminal region in each insulin analogs might influence the activity related to the effectiveness or time-related response in human body.

To complete the data, we superimposed the protein structure for each insulin analog and calculated in RMSD. Based on Kufareva and Abagyan, ${ }^{35}$ measuring the ligand's RMSD from its reference is located in the reaction complex after the optimum superimposition of the receptor molecules is the most common way to test the correctness of the docking geometry. The selection of this optimal superimposition is the first discretionary decision to be made by the evaluator, notably in the case where the receptor had to be modeled and the reference structure were substantially different. It is possible to measure the MSD for any form and subset of atoms; for example, CSD atoms in a whole protein, CSD atoms in all residues of a particular subset (e.g. transmembrane helixes, binding pockets or loops), all heavy atoms in a particular residue subset, or all heavy atoms in a small molecule ligand. Since the RMSD of each insulin analogs 3D structure varied and interestingly, the closest structure is Aspart and hINS proved by lowest RMSD score, leads a hypothesis of similarity characteristics for those two insulin in terms of structure and mechanism of action.

In this study, we used the protein-protein docking analysis to make deeper the exploration of relationship between structural and functional of each insulin analog. Docking methods is a computational procedure, originally proposed by Kuntz et al. $(1982)^{36}$, which virtually attempts to predict a complex of (usually) two binding partners. These binding partners are usually biological macromolecules (such as proteins, DNA/RNA, peptides) or small molecules (e.g., endogenous ligands, drugs). Small ligand molecule is aligned within the binding cavity of the target protein for structure-based small-molecule docking and a basic scoring mechanism measures the docking position for corresponding. For each position, the scoring function is produce a classification, and the resulting values are used to rank for various positions and ligands. There are two separate steps in the docking process in a methodological sense: the generation of the position and the scoring. The first applies to the strategies used to establish multiple conformations of ligands and proteins, also to coordinate different conformations of ligands within the protein's binding site. For a quantitative estimate of the position's efficiency, the latter of the scoring is needed in the docking process. ${ }^{36}$

Based on the data, affinity binding seems to represent the mechanism of action for each insulin analog. The higher affinity score is related to the time effect for each insulin. Rapid acting insulins such as Lispro and Aspart apparently have the higher affinity scores than the long-acting insulin such as Glargine and Detemir. Based on the review by Evans et al. $(2011)^{7}$ Lispro has been found to be similar to all glucose infusion steps in type 2 diabetes patients, except for $0.5 \mathrm{mmol} / 1$ lower insulin glulisine glucose which outflow in type 2 obesity patients. ${ }^{37}$ Another fast-acting insulin analog is Aspart, which the B-chain of insulin is altered. Insulin is substituted by an aspartic acid residue as part of the proline at position in $28 .{ }^{38}$ The result is close to the Lispro in terms of reducing protein's self-association. The action is started fifteen minutes or less after the injection and the peak occurs 31 to 70 minutes after the injection; the action lasts between 4 and 6 hours. It decreases $27 \mathrm{mg} / \mathrm{dL}(1.5 \mathrm{mmol} / \mathrm{L})$ of postprandial plasma glucose, 0.12 percent of $\mathrm{HbA} 1 \mathrm{c}$ and 50 percent of hypoglycemic events. Insulin 
Aspart has demonstrated quicker initiation of action and encouraged lower postprandial glucose levels relative to normal human insulin in clinical trials conducted, with non-pregnant healthy volunteers and patients with type 1 and type 2 diabetes. ${ }^{39}$

For the long-acting insulin, Glargine and Detemir, Glargin has another name, called Lantus. It is a basal insulin analog with a long-acting effect, to regulate the amount of blood sugar, and it's given once a day. It consists of microcrystals that slowly release insulin with a "peakless" profile, providing longterm action lasting 18 to $26 \mathrm{~h} .{ }^{40}$ Moreover, the second long-lasting rapid action insulin is Detemir,with the trading name is Levemir. It is an insulin analog in which the fatty acid (myric acid) at position B29 is bound to the lysine amino acid. Since it binds to albumin in the blood via its fatty acid at position B29, it is rapidly absorbed. Until it eventually dissociates itself from this complex. ${ }^{5}$

The identification results of insulin analog binding affinity and its structure might be important to explain about why the insulin analogs have their own time of action. The amino acid residues of each insulin analog could be modified in order to accelerate the action times, or delaying the peak time to adjust the patient necessity. Therefore, for future research in clinical study, the binding affinity data might be useful for clinical trial of the new residue sequence of insulin analogs.

In conclusion, the protein structures for each insulin analog shows if there is no significance differences, who assisted by pairwise alignment and RMSD score results. The interesting point is affinity binding of hINS and insulin analogs represents the rapid time action of each insulin. The higher the affinity score for hINSR and INS analog is the higher rate of action from insulin analog and vice versa. Lispro and Aspart insulin showing the high affinity binding towards insulin receptor emphasizing the fast-acting insulin, while the Glargin has lower affinity value represents the long-acting insulin.

\section{REFERENCES}

1. Quianzon, Celeste C, Cheikh I. The history of insulin. Diabetes. 1962;11(6):495-503.

2. Tibaldi JM. Evolution of insulin: from human to analog. Am J Med. 2014;127(10):S25-S38.

3. Bliss M. The history of insulin. Diabetes Care. 1993;16(3 SUPPL. 3):4-7.
4. Rosenfeld L. Insulin: discovery and controversy. Clin Chem. 2002;48(12):2270-88.

5. Chouhan R, Goswami S, Bajpai AK. Recent advancements in oral delivery of insulin: From challenges to solutions. In: Nanostructures for Oral Medicine. Elsevier Inc.; 2017:409-33.

6. Steele C, Steel D, Waine C. Type 1 diabetes mellitus. In: Steele C, Steel D, Waine C, editors. Diabetes and the Eye. Butterworth-Heinemann: Elsevier; 2008.p. 17-34.

7. Evans M, Schumm-Draeger PM, Vora J, King AB. A review of modern insulin analog pharmacokinetic and pharmacodynamic profiles in type 2 diabetes: Improvements and limitations. Diabetes, Obes Metab. 2011;13(8):677-84.

8. Humalog [Internet]. Silver Spring, Maryland: U.S. Food and Drug Administration [cited 2021 January 11]. Available from: http://www. accessdata.fda.gov/scripts/cder/drugsatfda/index. cfm?fuseaction=Search.DrugDetails

9. Novolog [Internet]. Silver Spring, Maryland: US Food and Drug Administration [cited 2021 January 11]. Available from: http://www. accessdata.fda.gov/scripts/cder/drugsatfda/index. cfm?fuseaction=Search.DrugDetails

10. Apidra [Internet]. Silver Spring, Maryland: US Food and Drug Administration [cited 2021 January 11]. Available from: http://www. accessdata.fda.gov/scripts/cder/drugsatfda/index. cfm?fuseaction=Search.DrugDetails

11. Lantus [Internet]. Silver Spring, Maryland: US Food and Drug Administration [cited 2021 January 11]. Available from: http://www. accessdata.fda.gov/scripts/cder/drugsatfda/index. cfm?fuseaction=Search.DrugDetails

12. Levemir [Internet]. Silver Spring, Maryland: US Food and Drug Administration [cited 2021 January 11]. Available from: http://www. accessdata.fda.gov/scripts/cder/drugsatfda/index. cfm?fuseaction=Search.DrugDetails

13. Hirsch IB. Insulin Analogues. $N$ Engl J Med. 2005;352(2):174-83.

14. Grunberger G. Insulin analogs are they worth it. Diabetes Care. 2014;37(6):1767-70.

15. Jing L, Nazleen FK, Thomas M, et al. Implementation of a health plan program switching from analogue to human insulin and glycemic control among medicare beneficiaries with type 2 diabetes. JAMA. 2019;321(4):374-84.

16. Davidson MB. The case for using human insulin. Am J Med. 2020;133(2):e23-e24.

17. Association AD. 9. Pharmacologic approaches to glycemic treatment: standards of medical care in diabetes - 2019. Diabetes Care. 2019;42(Supplement 1):S90-S102.

18. Crowley MJ, Matthew LM. Revisiting NPH insulin for type 2 diabetes: is a step back the path forward? JAMA. 2018;320(1):38-9. 
19. Lipska KJ, Irl BH, Matthew CR. Human insulin for type 2 diabetes: an effective, less-expensive Option. JAMA. 2017;318(1):23-4.

20. Lipska KJ. Insulin analogues for type 2 diabetes. JAMA. 2019;321(4):350-1.

21. Yang J, Zhang Y. I-TASSER server: New development for protein structure and function predictions. Nucleic Acids Res. 2015;43(W1):W174-W181. doi:10.1093/ nar/gkv342

22. Hall T, Biosciences I, Carlsbad C. BioEdit: An important software for molecular biology. GERF Bull Biosci. 2011;2(June):60-61.

23. Tamura K, Nei M. Estimation of the number of nucleotide substitutions in the control region of mitochondrial DNA in humans and chimpanzees. Mol Biol Evol. 1993;10(3):512-26.

24. Maiti R, Van Domselaar GH, Zhang H, Wishart DS. SuperPose: A simple server for sophisticated structural superposition. Nucleic Acids Res. 2004;32(WEB SERVER ISS.):590-4.

25. Yuan, S, Chan HCS, Hu Zhenquan. Using PyMOL as a platform for computational drug design. WIREs Comput Mol Sci 2017; 7:e1298

26. Dominguez $\mathrm{C}$, Boelens $\mathrm{R}$, Bonvin AMJJ. HADDOCK: A protein-protein docking approach based on biochemical or biophysical information. J Am Chem Soc. 2003;125(7):1731-7.

27. Whittaker J, Whittaker L. Characterization of the functional insulin binding epitopes of the full-length insulin receptor. J Biol Chem. 2005;280(22):2093220936.

28. Gilli P, Pretto L, Bertolasi V, Gilli G. Predicting hydrogen-bond strengths from acid-base molecular properties. the pka slide rule: toward the solution of a long-lasting problem. Acc Chem Res. 2009;42(1):3344.

29. Wahren J, Ekberg K, Johansson J, et al. Role of C-peptide in human physiology. Am J Physiol Endocrinol Metab. 2000;278(5):E759-68.
30. Wang S, Wei W, Zheng Y, et al. The role of insulin c-peptide in the coevolution analyses of the insulin signaling pathway: a hint for its functions. PLoS One. 2012;7(12).

31. Ido Y, Vindigni A, Chang K, et al. Prevention of vascular and neural dysfunction in diabetic rats by C- peptide. Science. 1997;277(5325):563-6.

32. Johansson J, Ekberg K, Shafqat J, et al. Molecular effects of proinsulin C-peptide. Biochem Biophys Res Commun. 2002;295(5):1035-40.

33. Shafqat J, Juntti-Berggren L, Zhong Z, et al. Proinsulin C-peptide and its analogues induce intracellular $\mathrm{Ca} 2+$ increases in human renal tubular cells. Cell Mol Life Sci. 2002;59(7):1185-9.

34. Munte CE, Vilela L, Kalbitzer HR, Garratt RC. Solution structure of human proinsulin C-peptide. FEBS J. 2005;272(16):4284-93.

35. Kufareva I, Abagyan R. Methods of protein structure comparison. Methods Mol Biol. 2012;857:231-57.

36. Kuntz ID, Blaney JM, Oatley SJ, Langridge R, Ferrin TE. A geometric approach to macromolecule-ligand interactions. J Mol Biol. 1982;161:269-88.

37. Luzio S, Peter R, Dunseath GJ, Mustafa L, Owens DR. A comparison of preprandial insulin glulisine versus insulin lispro in people with Type 2 diabetes over a 12-h period. Diabetes Res Clin Pract. 2008;79(2):269-75.

38. Carlos Antonio Negrato, Renan Magalhães Montenegro Junior, Lilia Maria Von Kostrisch, Maria Fatima Guedes, Rosiane Mattar MBG. Insulin analogues in the treatment of diabetes in pregnancy. Obstet Gynecol Clin North Am. 2007;34(2):275-91.

39. Setter SM, Corbett CF, Campbell RK, White JR. Insulin aspart: a new rapid-acting insulin analog. Ann Pharmacother. 2000;34(12):1423-31.

40. Hilgenfeld R, Seipke G, Berchtold H, Owens DR. The evolution of insulin glargine and its continuing contribution to diabetes care. Drugs. 2014;74(8):911-27. 